\title{
UNDERSTANDING LEARNERS' NEED OF ESP FOR ACCOUNTANCY PROGRAM AT VOCATIONAL SCHOOL
}

\author{
Semi Sukarni \\ English Language Education, Faculty of Teacher Training and Education \\ Universitas Muhammadiyah Purworejo, Indonesia \\ E-mail: semi.sukarni24@gmail.com
}

\begin{abstract}
APA Citation: Sukarni, S. (2020). Understanding learners' need of ESP for accountancy program at vocational school. English Review: Journal of English Education, 8(2), 273-282. doi: 10.25134/erjee.v8i2.2002.
\end{abstract}

Received: 18-01-2020

Accepted: 28-03-2020

Published: 01-06-2020

\begin{abstract}
The main objective of Vocational High School (SMK) is to prepare learners to specific job. At this school, learners are trained the major skills as well as the supportive skills. Language, in this case English, must support the hard skills for the communication at work. However, based on the preliminary research, most teachers use general English as teaching materials. Hence, this study aims to describe the learners' target need of learning English at accountancy program at Vocational High School and to identify English skills needed by students of accountancy program. There were 124 evelenth graders involved in this study which consisted of students of SMK 2 Purworejo and SMK 1 Wonosobo. To obtain the data, a questionnaire was used. The findings showed that $63.8 \%$ of the students want to look for a job after graduated, while $36.2 \%$ of them want to continue their study. Further, speaking is the most important skill and vocabulary related to the technical terms are needed by students. Another necessity is the availability of textbook containing ESP materials to support learners to develop their communication skill.
\end{abstract}

Keywords: ESP; learning need; need analysis; SMK; target need.

\section{INTRODUCTION}

The $21^{\text {st }}$ century skill framework is popular with 4Cs including critical thinking, problem solving, communication, and creativity and innovation (Forum, 2018). Learning International language particulary English is related one of the important skills in global communication. The language is used in communication at work for sharing thought, asking questions, conveying ideas and giving solution.

Communication skills are related to the term communicative competence in learning a language which cover four competence as it is explained by Canale and Swain as cited in Calce Murcia \& Olshtain, 2000, p.16 there are (1) linguistic and grammatical competence which consists of basic elemens of communication: sentence patterns, morphological inflection, lexical resources, and phonological system; (2) sociolinguistic competence, which consists of social and cultural knowledge require to use language appropriately such as formality, politeness; (3) discourse competence, which involves the selection, sequencing, and arrangement of words, structure to achive a unified spoken or written whole with reference to a particular message or context; (4) strategic competence, which includes the strategies and procedure relevant to language processing and production. It activates knowledge of other competencies and help the language users compensate for gaps and deficiencies in knowledge when they communicate. In the basis of these communicatice competence the language learners must be exposed to the use of language aspects in various contexts in different language events.

To achieve a good communication skill, institution must have an appropriate curriculum and instruction. As this study is focuses at Vocational High School, the school must have curriculum sets including the syllabus and materials which are needed by prospective graduates. Related to the act of the Republic of Indonesia No. 20 of 2003 on National Education System article 15 as cited in Mahbub (2018) states that vocational education is secondary education program for preparing learners for a specific job. To respond this statement, Vocational High School should provide the English skills which related to the specific skill achieved by the gradutes.

However, up to now in practice, there are no differences of English syllabus which used by senior high school and vocational high school.The materials contained in the syllabus of English subject are taught to students of Senior High School and Vocational High School. This matter, 
in fact, had been emphasized in Kusni, Syaamawi and Refnadi' finding that English for vocational high school students should be carefully redisigned and reconsidered before it is widely used throught the nation.

Related to Sukarni 's research finding on need analysis viewed by English teachers at vocational high school it was found that all teacher in the study taught English by using textbook that was required by government based on 2013 curriculum namely Bahasa Inggris SMA/MA/SMK/MAK written by Kementrian Pendidikan dan Kebudayaan. The content of the book is general English, it is not specifically written for vocational school. The general English does not specifically promote learners with language skills needed in the prospective work (Sukarni, 2019). Similar research finding showed that the teaching materials in VHS was not appropriate with the concept of ESP because it was too general, it didn't close to the students' field study (Ronaldo, 2016).

General English, henceforth (GE) is different from English for Specific Purpose, henceforth (ESP). ESP involves teaching and learning specific skills and language needed by particular learners for particular purpose-a set of skills that learners currently need in their work or will need in their professional career, whereas, GE is aimed at a very wide range of learners (Day \& Krzanowski, 2011).

The different between ESP and GE or general English language teaching, (henceforth general ELT) in term of external and internal goals for language teaching, Cook as cited in (Basturkmen, 2010). External goals is related to the uses of language outside the classroom. Internal goals relate to educational aims of the classroom. ESP teaching generally more concerned with external goals. In ESP learner engaged either in academic, professional or occupational pursuits.

Meanwhile ESP according to Dudley-Evans and St John as cited in (Basturkmen, 2010) focuses on when, where and why learners need the language either in study or workplace contexts. Decisions about what to teach, or how to teach are informed by descriptions of how language is used in the particular context where learners will work or study.

In order that the teaching materials in ESP syllabus meet with the learners' need in the prospective work, need analysis must be carried out. Need analysis is the process for the course developer to investigate what the learners need to know or be able to do in the targetr language in order for them to be able to use the language effectively in the chosen profession, work or study area (Basturkmen, 2013). Richards, (2001) had emphasized the purpose of need analysis, among them are to find out what the language skills a learners needs in order to perform a particular role, such as sales manager, tour guide, accountant, engineer; to identify a gap between what students are able to do and what they need to be able to do.

Related to the purpose, Hutchinson \& Waters, (1991) as cited in Nation and Macalister (2010) divide needs into target needs (what learner needs to do in the target situation) and learning need (what learner needs to do in order to learn). The target needs include necessities (what necessary the learners' use of language), lacks (what the learner lacks) and wants (what the learners wish to learn).

The need analysis must be carried out in order the course developer has information about the learner need to construct an English for specific materials. It is done commonly using questionnaire and interview to elicit the perception of learner needs as seen by stakeholders such as (learners, teachers and employers). The result of need analysis are generally used to determine the objective for the ESP course and to specify the sequence of instruction or content (language, tasks, activities, and skills) to be covered in the course.

Need analysis is seen as a key process in the development and revision of Language for Specific Purpose (LSP) as emphasized by Dudley-Evans and St John (1998), Baturkmen and Elder (2004) and Kim (2008) in Basturkmen (2013). She further explains that course developer investigates what learners need to know or be able to do in the target language in order for them to function effectively in the chosen profession, work or even study. A need analysis for students of accounting may indicate that the learners need to be familiar with vocabulary on topical areas such as loan and asset management and written genre such as financial statements and market reports and will need to draw on linguistic skills such as making notes while listening to telephone. These all to make the most of their accountancy studies (Basturkmen, 2013)

Several studies had carried out need analysis to determine the course contents for ESP in higher education such university in Kusnawati (2017); Lee (2016); Peodjiastuties and Oliver, (2017); Suyadi (2015) studies but limited studies conducted in treshold level or Vocational High 
School. There were few studies such as Kardijan, Emzir, \& Zaenal Rafli, (2017); Khusni, Syamwil, \& Rifnaldi, (2014) and Mahbub, (2018). However, none of the three studies focused on ESP for accountancy program at treshold level.

Lee's and Poedjiastuti and Oliver's study explored the perception of ESP course in university level. The difference is that Lee's study only involved the students perception of ESP course, while Poedjiastuti \& Oliver involved the stakeholders which included employers, teachers and students. The finding suggested on the important and useful of ESP course for the future job and the stakeholders acknowledge the important of English as global and international language.

Earlier studies on need analysis for ESP for accountancy in higher education did by Kusnawati (2017) and Suyadi (2015). These studies involved the students of accountancy program. The difference between the two studies were that Kusnawati's study explored the students ' perpective on their target and present English needs, while Suyadi's study aimed at improving materials for accounting program needed by students. The result suggested the target communication needs were English conversation skills for social interaction, whereas, their occupational disciplinary need was accounting terminology mastery. Meanwhile, Suyadi (2015) had suggested that the students of accounting program need a special materials in learning English which has relationship with study program of accountancy: reading, vocabulary and writing report.

Need analysis should be done by multiple stakeholders which include teacher, students, the current/future employesrs, the administration of the educational institution, etc. in designing the course syllabus as it emphasized by Huhta et al. as cited in Chovancova (2014). Sice there were no earlier studies as far as the writer found focusing on the need analysis of ESP for vocational high school for accountancy program viewed from the learners, this study aims: (1) to describe the learners target need of learning English at accountancy program of vocational high school; (2) to identify English skills needed by students of accountancy program.

\section{METHOD}

The research belongs to qualitative research. It also belongs to exploratory research as the writer explored the information about target needs which include necessities, lacks and wants and learning needs. The result of the need analysis can be used to develop a new syllabus and finally a new textbook which meets with the learners' needs.

This study was conducted at the chosen Vocational high school (VHS/SMK) Business and Managemen in Purworejo and Wonosobo Regencies of Central Java. The participants were the students in Accountancy Program of the eleventh grade.

Questionnaire was used to collect the data about the need analysis viewed from the students. The questions in the questionnaire covers both closed-ended and open-ended questions. An openended question requires participants in any way that they please and provide primarily qualitative data. On the other hand, closed-ended question requires participants to choose limited number of responses which are predetermined by the researcher and it primarily provides quantitative data (Johnson and Christensen, 2012, p. 169). There were 12 Likert-scale items to obtain the data on lack and 1 item on necessity and three items/open-ended questions. A four-point Likert scale response includes Strongly Agree, Agree, Disagree, and Strongly Disagree.

Thematic data analysis was used to analyze the qualitative data about the learners' needs for ESP teaching materials. Descriptive quantitative data was used to analyze the quantitative data by using descriptive statistics in a form of simple percentage calculation for the item analysis.

\section{RESULTS AND DISCUSSION Learners' target need of learning English}

To explain about learners' target need of learning English, there were three questions had to be answered by the students. The questions were related to the importance of learning English viewed by the learners; the sequence of the important language skills viewed by the learners and the sequence of the important language aspects viewed by the learners. The findings from research data were presented below.

\section{Target need for learning English viewed from} the learners

The target need for learning English here means the learners' reason for learning English whether they learn English for preparing further study in higher institution or for looking for a job after the learners graduate. The finding is presented in the table below. 
Table 1. Target need for learning English viewed from the learners

\begin{tabular}{cccc}
\hline No & Target need for learning English & Total & Percentage (\%) \\
\hline 1 & Preparing for further study & 45 & 36.2 \\
2 & Looking for a job & 79 & 63.8 \\
& & 124 & 100 \\
\hline
\end{tabular}

Table 1 shows the comparison of the number of students for the reason of learning English. It shows that Looking for a job is more than Preparing for further study $(63.8>36.2)$. It shows that students in vocational school tend to have aim to work rather than to further study. It implies that the content of the English teaching materials needed by students of Vocational School is not only General English (GE) but also materials which are related to the working situation in the future job, in this case is ESP related to accounting or financial matters. If the schools only teach students with GE, it means that they only accommodate the students who want to continue studying in higher institution, however, they do not accommodate the students who want to work after graduate.

\section{The sequence of the importance of language skills needed by learners}

The second point about the target need is related to the sequence of importance of language skills which include listening, speaking, reading and writing which is needed by learners. In the learners" view which language skill they think is most important among four skills, which one the second, the third and the fourth. This information is important in order to provide learning experience which skill should receive emphasis than other skills which related to the learners' need. The finding is presented in the table below.

Table 2. The sequence of the importance of language skills needed by learners

\begin{tabular}{cccc}
\hline No & Language Skill & Total & Percentage \\
\hline 1 & Listening & 22 & 17.7 \\
2 & Speaking & 69 & 55.6 \\
3 & Reading & 20 & 16.1 \\
4 & Writing & 14 & 10.4 \\
& & $\mathbf{1 2 4}$ & $\mathbf{1 0 0}$ \\
\hline
\end{tabular}

Table 2 shows that the most important language skill needed by learners is speaking as it is seen that speaking has the highest percentage compare to other skills. It is possible that the learners had an assumption that speaking is for communication with other people particularly in working situation. It is seemed that the learners had already known that communication is needed for the prospective graduates in relation with one of the $2^{\text {st }}$ century skills related to $4 \mathrm{Cs} 21^{\text {st }}$ century skills framework. However, communication skills here which refering for sharing thought, questioning, conveying ideas and giving solution is not only practice in speaking but also in writing. At the same time to be able to speak well, learners have to be exposed with listening in order for the graduates meet the job requirements they need to learn and practice during vocational school education. This finding support the earlier research finding from Kusnawati (2017) that the target needs was English conversation skills for social interaction.

\section{The sequence of the importance of language aspects}

The third point is about the target need related to the sequence of importance of language aspects which include vocabulary, grammar and pronunciation which is needed by learners. The researcher would like to know, in learners view which one they think is the most important or urgent among the three language aspects. As this information is also important to provide learners learning materials which meet with the learners' need. The finding is presented in the table below.

Table 3. The sequence of the importance of language aspects needed by learners

\begin{tabular}{clcc}
\hline No & Language aspects & Total & Percentage \% \\
\hline 1 & Vocabulary & 71 & 57.2 \\
2 & Grammar & 37 & 29.8 \\
3 & Pronunciation & 16 & 12.9 \\
& & $\mathbf{1 2 4}$ & $\mathbf{1 0 0}$ \\
\hline
\end{tabular}


Table 3 shows that the most important language aspect needed by learners is vocabulary. This answer related to the answer for the most important language skill - speaking. The learners had already had assumption that in order to able to communicate in English, the learners need to have large number of vocabulary and the frequent practice in speaking. This is the resason why vocabulary is the most important. This finding supports the earlier research finding from Kusnawati (2017) about the need of accounting terminology or technical term of vocabulary. However, other aspects- grammar and pronunciation are also important. Without the language three aspects learners cannot involve in English communication either active or passive.

The three questions had given information about the target need viewed by learners. This information is important for the stake holders of vocational school educationl in order to provide learning materials which are needed by learners in order to meet the future need. As it related to the Lenard and Pintaric's study on students and employeers and it resulted that it was imperative need for communicative competency at the workplace. It is advised that schools design and implement a specialized course aiming to develop listening, writing, teamwork and presentation skills (Lenard \& Pintaric, 2018).

\section{The lacks in the present textbooks used by Vocational High School}

There are some questions in the questionnaire which try to analyze the textbook used at present by VHS students in order to understand real condition about the textbook. The information is presented below.

Table 4. Questionnaire result of students' response of textbook quality

\begin{tabular}{llcccc}
\hline No & \multicolumn{4}{c}{ Teacher Response (\%) } \\
\cline { 2 - 5 } & \multicolumn{1}{c}{ SA } & A & D & SD \\
\hline 1 & $\begin{array}{l}\text { English textbooks for SMK in general relevant to } \\
\text { the students' need of English }\end{array}$ & 18.5 & 36.2 & 43.5 & 1.6 \\
2 & $\begin{array}{l}\text { The exposure in textbook is very relevant. } \\
\text { The content of vocabulary in textbook is relevant } \\
\text { to the students' skill }\end{array}$ & 13.7 & 40.3 & 45.2 & 0.8 \\
4 & $\begin{array}{l}\text { The content of grammar related to the students' } \\
\text { skill. }\end{array}$ & 4 & 42.1 & 42.7 & 3.2 \\
5. & $\begin{array}{l}\text { Communicative expressions in textbook is } \\
\text { related to the students' skill }\end{array}$ & 18.1 & 36.2 & 44.3 & 3.2 \\
6 & $\begin{array}{l}\text { Reading text in textbook is related to the } \\
\text { students' skill }\end{array}$ & 13.7 & 40.3 & 42.7 & 3.2 \\
7 & $\begin{array}{l}\text { Context for speaking practice in textbook is } \\
\text { related to the students' skill. }\end{array}$ & 16.1 & 38.7 & 43.5 & 3.2 \\
8 & $\begin{array}{l}\text { Textbooks contain various learning activities. } \\
\text { Learning activities provided make students } \\
\text { participate actively. }\end{array}$ & 18.1 & 36.2 & 46.7 & 0.8 \\
10 & $\begin{array}{l}\text { Textbooks contain various evaluation types } \\
\text { including authentic assessment. }\end{array}$ & 16.1 & 32.2 & 50 & 1.6 \\
11 & $\begin{array}{l}\text { Textbooks stimulate students to learn English } \\
\text { according to their skill. }\end{array}$ & 16.1 & 16.1 & 50 & 3.2
\end{tabular}

There are eleven questions for textbook analysis which asked about the condition of textbooks that used at VHS at present viewed from the students. The students had to give response to 11 items related to quality of the textbooks used at present by giving response Strongly Agree (SA), Agree (A), Disagree (D) and Strongly Disagree (SD). Based on the data analysis it was found that the percentage of response Disagree (D) had highest among other responses, particulary Strongly Agree (SA) or Agree (A).
Question 1: English textbooks for SMK in general relevant to the students' need of English.

There were $45.1 \%$ students answer in Disagree. It means that the textbook at present is less relevant to the students' need of English in specific areas of accounting.

Question 2: The exposure in textbook is very relevant.

There were $46 \%$ students answer Disagree. It means the exposure in textbook is not really relevant to the target needs - for example the exposure related to the communication in the financial institution. 
Question 3: The content of vocabulary in textbook is relevant to the students' skill.

There were $45.9 \%$ students answer Disagree. It means many students feel that the content of vocabulary in textbook is less relevant to the students' skill related to the technical terms used in accountancy.

Question 4: The content of grammar related to the students' skill.

There were $53.2 \%$ students answer Disagree. It means the majority of students feel that the content of grammar is not related to the students' skill. In other words, the grammar which contained in the textbook is not relevant with the grammar/sentence construction for English for accountancy.

Question 5: Communicative expressions in textbook is related to the students' skill.

There were $47.5 \%$ students answer Disagree. It means that many students think that the communicative expressions in textbook is not related to the students' skills for conveying ideas, question and solution.

Question 6: Reading text in textbook is related to the students' skill.

There were $45.9 \%$ students answer Disagree. It means many students feel that reading texts in textbook are related to the students' skills in accountacy for example text for explaining account, Management Accounting, Job in accounting, etc.

Question 7: Context for speaking practice in textbook is related to the students' skill.

There were $46.7 \%$ students answer Disagree. It means that many students think that the Context for speaking practice in textbook is little related to the students' skills in more specific field of accountancy.

Question 8: Textbooks contain various learning activities.

There were $47.5 \%$ students answer Disagree. It means that many students think that textbooks do not contain various learning activities for students to learn and practice English.

Question 9: Learning activities provided make students participate actively.

There were $51.6 \%$ students answer Disagree. It means that majority of students feel that the learning activities provided do not make students participate actively to develop their communication skills.
Question 10: Textbooks contain various evaluation types including authentic assessment.

There were $53.2 \%$ students answer Disagree. It mean that the majority of students think that the textbooks contain do not various evaluation types including authentic assessment such as performance, oral practice, port folio, etc.

Question 11: Textbooks stimulate students to learn English according to their skill.

There were $53.2 \%$ students answer Disagree. It means that the majority of students feel that the textbooks do not stimulate students to learn English according to their skill needed in the specific area of accountany.

Based on the analysis above it can be stated that the textbooks used at present are a bit far from what students expected. For example: the exposure, content of vocabulary, communicative expressions reading text, context for speaking practice and learning activities are not related to the speacific field of study-accountancy.

Based on the data analysis the lack in learning need shows that the quality of the published textbooks in the market which are used at present are not enough to provide the students communicative competence needed in the specific field of accountancy. As there are some weaknesses like irrelevant with the students' skills in terms of vocabulary, context, grammar, functional expression, reading texts; lack of relevant exposure, less various evaluation types, less learning activities, unstimulated learning activities. This finding is in line with Mahbub's research finding that the English teaching and laerning were lack of opportunity to develop oral communication skill, lack of quality textbook and small quantity of English related to the study program. This result is also in line with Sukarni's (2019) earlier research on textbook quality analysis viewed from teacher. The group of teachers in the study acknowledged the weakness of textbook used at present.

\section{The learner target need on "want"}

A question in the questionnaire was given to respond the lack in the learning need by asking students to what extend they need of publishing a textbook containing ESP. The students had response by either SA for Strongly Agree, A for Agree, D for Disagree and SD for Strongly Disagree. The calculation and percentage were made and presented in the chart below. 


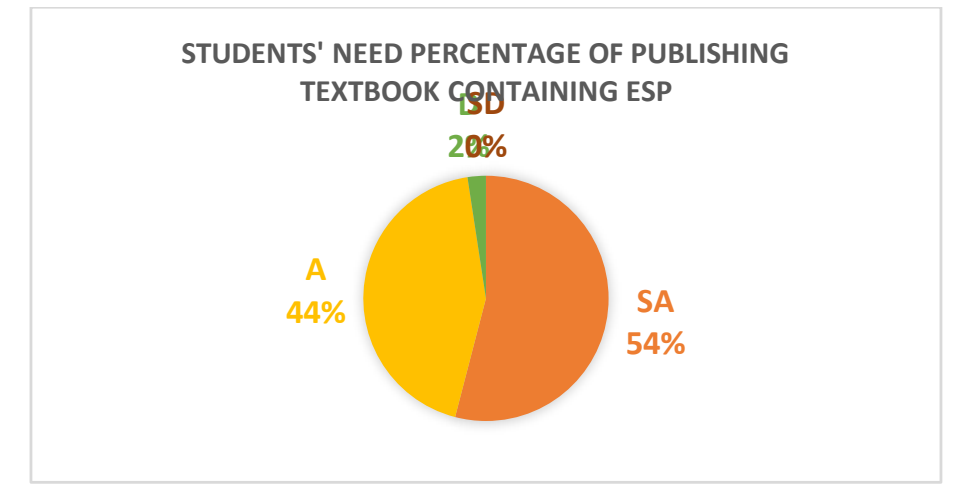

Figure 1. Students ' need of publishing textbook containing ESP

The chart shows the students' percentage of the want: to publish textbook containing ESP with the highest response percentage on Strongly Agree $(\mathrm{SA})=54 \%$, the Agree (A) $44 \%$. While response Disagree was only very small portion $=$ $2 \%$ and Strongly Disagree was none. If the response for SA and A is combined $=98 \%$. it can be said that $98 \%$ students agree to have a textbook containing ESP. It is in line with Lee's finding that $80 \%$ students thought ESP course are useful for the future job.

\section{English skills needed by students of accountancy program}

The next questions of the learning need related to want was about the textbook items and skills needed by the students to respond to necessities. The respondens had to give a tick mark on the items provided by the author for the future ESP textbook. The responden responses was counted and made into the percentage. The response was presented below.

Table 5. Textbook ESP Items viewed by students

\begin{tabular}{clcc}
\hline \multirow{2}{*}{ No } & \multicolumn{1}{c}{ Textbook Items } & $\begin{array}{c}\text { Total } \\
\text { Response }\end{array}$ & Percentage (\%) \\
\hline 1 & $\begin{array}{l}\text { Contexts in the textbook contain situation used in English } \\
\text { for accountancy program. }\end{array}$ & 112 & 90 \\
2 & $\begin{array}{l}\text { Vocabulary related to in English for accountancy program. } \\
3\end{array}$ & 119 & 96 \\
& $\begin{array}{l}\text { It contained language expressions needed in working } \\
\text { environment. }\end{array}$ & 121 & 98 \\
4 & $\begin{array}{l}\text { It contained grammar or text structure which are used in oral } \\
\text { and written communication. }\end{array}$ & 116 & 93.5 \\
5 & It contained various learner-centered learning activities. & 91 & 73.3 \\
6 & It contained both formative and alternative assessment. & 90 & 72.5 \\
\hline
\end{tabular}

Table 5 shows the response about the textbook items which are expected by students in the learning needs. Based on the total response it shows the high percentage for each question in the questionnaire. It means to response the lack fond in the textbooks used at present. The students expected that the textbook for accountancy program contains (1) Contexts of situation used in English for accountancy program; (2) vocabulary related to English for accountancy program; (3) language expressions needed in working environment; (4) grammar or text structure which are used in oral and written communication; (5) various learner-centered learning activities; and (6) formative and alternative assessment.

In the second want analysis, the author provided materials and skills related to the accounting matters to provide the ESP-content material for the VHS accountancy program. The students are assigned to give a tick mark for the skills and materials they think are appropriate to be learned in English in accountacy program. A calculation and percentage were made and presented in the table below. 
Table 6. ESP materials and Skills needed by accounting students

\begin{tabular}{llcc}
\hline No & Materials and Skills & $\begin{array}{c}\text { Percentage (\%) } \\
\text { Agree }\end{array}$ & $\begin{array}{c}\text { Percentage (\%) } \\
\text { Disagree }\end{array}$ \\
\hline 1 & Understanding Cultural Diversity and Socilizing & 85 & 15 \\
2 & Dealing with Numbers & 95 & 5 \\
3 & Banking & 100 & 0 \\
4 & Accounting and Financial Statements & 100 & 0 \\
6 & Central Banking and Money & 100 & 0 \\
7 & Job in Accounting & 100 & 0 \\
8 & Accounting Principle & 100 & 0 \\
9 & Explaining Account & 100 & 0 \\
10 & Tax Accounting & 100 & 0 \\
11 & Management Accounting & 100 & 0 \\
12 & Retail Banking & 100 & 0 \\
13 & Foreign Exchange & 100 & 0 \\
14 & Writing Report & 98.3 & 1.7 \\
15 & Exchange Rate & 94.3 & 4.8 \\
16 & Investment & 99.2 & 0.8 \\
\hline
\end{tabular}

Table 6 shows the students' response about the materials and skills needed by the students of accounting program. Based on the percentage in the table the least percentage of Agree is $85 \%$ and the highest is $100 \%$. It can be stated that the students agree with all topics offered by the author. The students believed that the topics must be learned and covered in ESP-based textbook of accounting program. By learning these topics they will be exposed to the accounting context and situation, they will learn vocabulary related to accounting, practise language skills that have relevance with accounting. This finding is accordance with Guerid and Mami's finding who suggested that the participants in their study who consisted of finance and accounting staff that ESP should provide some topics like financial reports, accounting, auditing, etc., skills like reading and understanding financial report, grammar items like tenses, repoted speech, etc. and authentic and relevant materials like earning per share, account payable, dividents, etc. (Guerid \& Mami, 2017).

\section{CONCLUSION}

Based on the finding and discussion, there are conclusion that can be drawn as follows. The target needs viewed by learners as the necessities showed that vocational high school prospective graduates tend to find a work compared to continue studying. As the majority prospective graduates preaparing to work, they perceived speaking is the most important skill in order to communicate in working situation. The students chose vocabulary was the most important language aspect in order they will be able to carry out communication.
The students perceived the lack in the target need was the textbook used at present. As the school used Bahasa Inggris for SMA/SMK which contained GE. The book does not equip enough English aspects and skills needed in the working situation.

The want analysis in the target need shows 98\% of the students need an English textbook containing ESP materials in order that they can practice both written or oral communication for preparing job requirement.

The students expected that the ESP textbook contain items which cover good criteria for textbook such as having language aspects vocabulary, grammar, skill activities, learning experience and assessment. The students perceived that the ESP textbook contained materials and skills which are related to accountancy to support their specific competence.

The implication from the findings of this study is related to the course plan and teaching practice at Vocational High School. In planning the lesson, the teachers of English language should understand the learners' target need: preparing for work. So, lessons should accomodate the needs. Besides teaching GE, teachers should supply ESP materials which are taken from different sources from the internet covering the language aspects such as vocabulary related to the technical terms of accounting and the balance language skills for developing both spoken and written communication skills to equipt the students' target need. This is in line with the implication suggested by Dahbi (2016) that ESP teacher as a researcher to be in constant touch with the students. They should try to diagnose the learners' need and evaluate its 
ENGLISH REVIEW: Journal of English Education

Volume 8, Issue 2, June 2020

effectiveness of the language course (Dahbi, 2016).

For the policy maker in SMK curriculum developer, it is necessary to add teaching hour for English subject so that learners have more learning period to learn and practice English for communication.

\section{REFERENCES}

Basturkmen, H. (2010). Developing courses in English for specific purpose. New York: Palgrave Macmillan.

Basturkmen, H. (2013). Needs analysis and syllabus design for language for specific purposes. The Encyclopedia of Applied Linguistics, 1-8. doi: 10.1002/9781405198431.wbeal0861.pub2.

Chovancova, B. (2014). Needs analysis and ESP course design: Self-Perception of language needs among pre-service students. Study in Logic, Grammar and Rhetoric, 38(51), 43-57. doi: 10.2478/slgr-2014-0031.

Dahbi, M. (2016). Toward an ESP course for engineering students in vocational schools in Morrocco: The case of the national school of applied science. Arab World English Journal, (December), 72-81.

Day, J. \&, \& Krzanowski. (2011). Teaching English for specific purposes: An introduction. Singapore: Cambridge University Press.

Forum, W. E. (2018). The future of jobs report 2018. Geneva: World Economic Forum.

Guerid, F., \& Mami, N. A. (2017). Designing an ESP syllabus for finance. The Journal of Teaching English for Specific and Academic Purposes, 5(1988), 771-780. doi: 10.22190/JTESAP1704771G.

Hutchinson, \& Waters. (1991). English for specific purposes. New York: Cambridge University Press.

Kardijan, D., Emzir, E., \& Rafli, Z. (2017). The gap between learning need and its implementation in English for hospitality specific purposes
p-ISSN 2301-7554, e-ISSN 2541-3643

https://journal.uniku.ac.id/index.php/ERJEE

program, $\quad 6(1), \quad 125-136 . \quad$ doi: 10.25134/erjee.v6i1.779.

Khusni, Syamwil, \& Rifnaldi. (2014). Diagnosing the need for English at vocational school: Redesign the curriculum 2013? (pp. 4-5).

Kusnawati, A. (2017). Assessing English language needs through the lens of ESP - EFL students' perspectives. Conaplin 9, 82, 52-57.

Lee, C. (2016). Principles and practices of ESP course design - A case study of a university of science and technology. International Journal of Learning, Teaching and Educational Research, 15(2), 94-105.

Lenard, D., \& Pintaric, L. (2018). Comparison of employers' and students' perceptions regarding communication skills. The Journal of Teaching English for Specific and Academic Purpose, 6, 63-82.

Mahbub, M. (2018). English teaching in vocational high school: A need analysis. JEELS, 1(29), 229-258.

Nation, I. S. P., \& Macalister, J. (2010). Language curriculum design. London: Routledge.

Peodjiastuties, D., \& Oliver, R. (2017). English learning needs of ESP learners: Exploring stakehoder perception at an Indonesian university. TEFLIN Journal, 28(January 2017), $1-21$.

Richards. (2001). Curriculum development in language teaching. Cambridge: Cambridge University Press.

Ronaldo, O. (2016). Teaching material For English subject in vocational. Proceeding of the Fourth International Seminar on English Language and Teaching (ISELT-4), 170-179.

Sukarni, S. (2019). A need analysis for ESP-content materials for accountancy programme at vocational high school. ELLIC. doi: 10.4108/eai.27-4-2019.2285343.

Suyadi, S. (2015). English for specific purposes for accounting students. Proceedings of ISELT FBS Universitas Negeri Padang, 3, 467-473. 
Semi Sukarni

Understanding learners' need of ESP for accountancy program at vocational school 